\title{
Pengaruh Alih Fungsi Telajakan Depan Rumah Menjadi Artshop terhadap Kenyamanan dan Estetika Lansekap Desa Tegallalang
}

\author{
I WAYAN PASEK HARIMBAWA ${ }^{1}$, I MADE SUKEWIJAYA ${ }^{1 *}$ \\ NI WAYAN FEBRIANA UTAMI ${ }^{1}$ \\ 1. Program Studi Agroekoteknologi, Fakultas Pertanian, Universitas Udayana \\ Jl. P.B. Sudirman Denpasar 80362, Indonesia \\ *E-mail: imsukewijaya@yahoo.com
}

\begin{abstract}
The Effect of Telajakan-Front Yard Conversion into an Artshop Toward Human Comfort Index and Landscape Aesthetic in Tegallalang Village

Telajakan, a Balinese typical home yard, has located in front, right or left, or in the back of the yard. The study only focused on telajakan front yard along the way of Tegallalang Village which is usually used as a garden or planted area, although many of them turning into an artshop. The purpose of the study was to determine the effect of telajakan conversion into an artshop using user's comfort index and landscape aesthetic measurement. Methods used in this study was temperature humidity index (THI) with the data of temperature and humidity. In addition, to assessed the aesthetic quality of the landscape used scenic beauty estimation (SBE) method by taking a photo of each landscape element representing the land use. Result showed that user's comport index was low (THI valued ranged from 24,47 to 27,39 ) and categorized as uncomfortable to the tropics area. Further, the aesthetic quality resulted that the lowest SBE quality was $-80,21$ and highest SBE quality was 138,42 . The aesthetic quality of the majoring landscape along the way of Tegallalang valued as a low category $(53,33 \%)$, medium category $(28,88 \%)$, and high category $(17,77 \%)$. As a results, the conversion of telajakan into an artshop caused low of user's comfort index and low of aesthetic quality to the landscape.
\end{abstract}

Keywords: comfort index, landscape aesthetics, telajakan, temperature humidity index (THI), scenic beauty estimation (SBE).

\section{Pendahuluan}

\subsection{Latar Belakang}

Desa Tegallalang merupakan desa di Kecamatan Tegallalang Kabupaten Gianyar yang berada pada ketinggian 510-550 m dpl, dengan curah hujan rata-rata $1955 \mathrm{~mm} /$ tahun (Profil Desa Tegallalang, 2013). Desa Tegallalang adalah salah satu desa tujuan pariwisata dengan kekhasan budaya, kearifan lokal, dan keindahan alamnya yang sangat menarik perhatian para wisatawan. Penduduk lokal maupun pendatang memanfaatkan peluang ini dengan berbagai kreativitas usaha, dari usaha kecil hingga berskala besar untuk 
mendukung kegiatan pariwisata. Sektor perdagangan merupakan salah satu sendi perekonomian yang memberikan sumbangan pemasukan yang cukup dominan bagi daerah ini. Salah satu bidang usaha perdagangan yakni artshop yang menyediakan berbagai cendera mata untuk keperluan wisatawan asing maupun wisatawan domestik (Statistik Daerah Kecamatan Tegallalang, 2012).

Pembangunan artshop yang terjadi di telajakan depan rumah sepanjang jalan raya Desa Tegallalang dari tahun ke tahun mengalami peningkatan, pada tahun 2009 tercatat sebanyak 576 dan tahun 2011 sudah mencapai 590 unit artshop (Statistik Daerah Kecamatan Tegallalang, 2012). Pembangunan artshop merupakan salah satu usaha untuk meningkatkan perekonomian desa. Namun, salah satu permasalahan penting yang dihadapi dalam pembangunan ekonomi adalah bagaimana menghadapi perdagangan yang tidak sejalan antara pemenuhan kebutuhan pembangunan di satu sisi dan upaya mempertahankan kelestarian lingkungan di sisi lain (Fauzi, 2004). Pembangunan artshop memiliki pengaruh positif dan negatif terhadap lansekap desa. Beberapa komponen lansekap yang mungkin terpengaruh dari alih fungsi telajakan adalah kenyamanan dan estetika lansekap Desa Tegallalang.

Alih fungsi telajakan menyebabkan telajakan yang merupakan salah satu kearifan lokal Bali dan dapat meningkatkan estetika wilayah menjadi hilang. Lansekap yang didominasi oleh elemen vegetasi cenderung lebih disukai masyarakat dan dianggap indah, sedangkan lansekap yang didominasi oleh elemen bangunan cenderung kurang disukai dan dianggap kurang indah atau estetik (Meliawati, 2003). Untuk mengetahui pengaruh alih fungsi tersebut maka dilakukan penelitian yang berjudul "Pengaruh Alih Fungsi Telajakan Depan Rumah Menjadi Artshop terhadap Kenyamanan dan Estetika Lansekap Desa Tegallalang".

\subsection{Tujuan Penelitian}

a) Mengetahui pengaruh alih fungsi telajakan depan rumah menjadi artshop terhadap kenyamanan pengguna lansekap sepanjang jalan raya Desa Tegallalang,

b) Mengetahui pengaruh alih fungsi telajakan depan rumah menjadi artshop terhadap estetika lansekap sepanjang jalan raya Desa Tegallalang.

\subsection{Ruang Lingkup Penelitian}

a) Kenyamanan yang akan diteliti adalah indeks kenyamanan yang ditentukan dengan menggunakan pendekatan temperature humidity index (THI),

b) Estetika lansekap yang akan diteliti adalah keindahan pemandangan (scenic beauty) dengan metode scenic beauty estimation (SBE).

\subsection{Hipotesis}

Hipotesis dalam penelitian ini adalah semakin besar alih fungsi telajakan menjadi artshop, maka kenyamanan dan estetika lansekap semakin rendah. 


\section{Metode}

\subsection{Waktu dan Tempat Pelaksanaan}

Penelitian ini dilaksanakan pada bulan Desember 2013 sampai dengan Februari 2014, bertempat di Desa Tegallalang, Kecamatan Tegallalang, Kabupaten Gianyar Provinsi Bali.

\subsection{Bahan dan Alat}

Penelitian ini menggunakan bahan antara lain: kuesioner, data curah hujan, dan slide foto untuk menilai SBE. Sedangkan alat yang digunakan antara lain: termometer untuk mengukur suhu udara, higrometer untuk mengukur kelembaban udara, kamera digital untuk dokumentasi, alat tulis, dan perangkat komputer untuk mengolah data.

\subsection{Sumber Data}

\subsubsection{Data Primer}

Data suhu dan kelembaban udara, diperoleh dengan melakukan pengukuran langsung di lapangan menggunakan alat. Data untuk mengetahui nilai estetika diperoleh dari pengambilan foto yang akan dinilai oleh responden.

\subsubsection{Data Sekunder}

Data sekunder diperoleh dari Profil Desa Tegallalang, Statistik Daerah Kecamatan Tegallalang, dan laporan-laporan yang terkait dengan penelitian ini.

\subsection{Metode Pengumpulan Data}

\subsubsection{Pengumpulan Data Indeks Kenyamanan}

Dalam mengetahui indeks kenyamanan dengan pendekatan THI di Desa Tegallalang, indikator yang diukur adalah suhu dan kelembaban udara. Pengukuran suhu dilakukan dengan menggunakan termometer dan kelembaban dengan menggunakan higrometer. Penelitian dilaksanakan di sepanjang jalan raya Desa Tegallalang. Pengukuran dilakukan di beberapa titik, titik pengukuran diambil setiap jarak $500 \mathrm{~m}$. Pengukuran dilakukan setiap 1 minggu sekali, yaitu pada pagi pukul 06.00 - 08.00, siang pukul 12.00 14.00 dan sore pukul 17.00 - 19.00 WITA. Pengukuran suhu dilakukan pada ketinggian $\pm 1,5$ meter dari permukaan tanah. Menurut Tjasyono (1992), dipilihnya tinggi $\pm 1,5$ meter karena pada ketinggian ini memungkinkan data klimatologi dapat berlaku untuk daerah yang lebih luas. Guna kemudahan dalam pengukuran, digunakan sebilah kayu sepanjang $\pm 1,6 \mathrm{~m}$ sebagai penopang termometer dan higrometer. Termometer dan higrometer diikatkan pada bagian ujung atas kayu. Ujung kayu dibuatkan tudung secukupnya untuk menaungi termometer dan higrometer dari sinar matahari langsung.

\subsubsection{Pengumpulan Data Estetika Lansekap}

Metode untuk mengetahui estetika lansekap di sepanjang jalan raya Desa Tegallalang mengikuti prosedur metode scenic beauty estimation (SBE) yang dikemukakan oleh Daniel dan Boster (1976). Langkah pertama yang dilakukan adalah pemotretan dan penentuan vantage point (titik dimana lansekap sekitarnya dipotret), didasarkan pada lansekap yang mewakili berbagai tata guna lahan utama dan tipe lansekap (Gunawan, 
2005). Setelah diperoleh 45 vantage point, selanjutnya dilakukan pemotretan. Pemotretan lansekap memperhatikan dominansi dan proporsi elemen lansekap yaitu angkul-angkul, telajakan, pedestrian, artshop dan jalan raya. Langkah kedua yaitu penilaian oleh responden. Penilaian dilakukan dengan mempresentasikan foto hasil pemotretan dalam tampilan slide untuk memperoleh penilaian responden. Presentasi slide foto menggunakan program Microsoft Office Power Point 2010. Slide foto yang ditampilkan berjumlah 45 dengan waktu penayangan 8 detik untuk tiap slide. Teknis pengisian kuesioner berupa pemberian skor 1 sampai 10 terhadap setiap slide yang ditampilkan. Skor 1 adalah lansekap yang paling tidak disukai sedangkan skor 10 adalah yang paling disukai. Jumlah responden pada penelitian ini adalah 25 orang, yaitu mahasiswa semester IV, VI, dan VIII Program Studi Agroekoteknologi Fakultas Pertanian UNUD.

\subsection{Metode Analisis Data}

\subsubsection{Metode Analisis Data Indeks Kenyamanan}

Metode yang digunakan analisis indeks kenyamanan adalah pendekatan THI. Pada metode ini, data suhu dan kelembaban yang diperoleh dari hasil pengukuran kemudian dihitung nilai THI dengan rumus dari Niewolt (1998), yaitu:

$$
\mathrm{THI}=0,8 \mathrm{~T}+(\mathrm{RH} \times \mathrm{T} / 500)
$$

Keterangan:

THI= temperature humidity index

$\mathrm{T}=$ suhu atau temperatur udara $\left({ }^{\circ} \mathrm{C}\right)$

$\mathrm{RH}=$ kelembaban udara (\%)

THI adalah indeks yang menunjukkan tingkat kenyamanan suatu area secara kuantitatif berdasarkan nilai suhu dan kelembaban udara relatif. Diena (2009) menyatakan bahwa indeks kenyamanan dalam kondisi nyaman ideal bagi manusia Indonesia berada pada kisaran THI 20-26. Tingkat kenyamanan ini kemudian dibagi menjadi 3 kondisi yaitu nyaman (THI 20-23), sedang ( THI 24-26), dan tidak nyaman ( $\mathrm{THI}>26$ ).

\subsubsection{Metode Analisis Data Estetika Lansekap}

Data presentasi slide diolah secara kuantitatif dengan menggunakan metode statistik. Rangking penilaian SBE dapat dihitung dengan rumus Daniel dan Boster (1976):

$$
\text { SBEX }=(Z L X-Z L S) \times 100
$$

Keterangan:

SBEX: nilai SBE titik ke $X$

ZLX: Nilai rata-rata z titik ke $X$

ZLS: Nilai rata-rata z titik yang digunakan sebagai standar.

Kualitas estetika dikelompokkan ke dalam 3 kategori, yaitu estetika tinggi, sedang, dan rendah. Berdasarkan sebaran nilai SBE untuk semua foto yang dinilai, apabila dibuat 
klasifikasi menjadi 3 dengan menggunakan jenjang sederhana (simplified rating), dengan rumus yang dikemukakan oleh Khakhim dkk (2008):

$$
I=\frac{\text { Nilai tertinggi }- \text { nilai terendah }}{\text { Jumlah kelas }}
$$

Setiap rangking dihitung jumlah frekuensi kumulatif, peluang kumulatif, dan nilai z (Daniel dan Booster, 1976). Pengelompokan didasarkan oleh sebaran normal dengan uji sebaran normal menggunakan software Microsoft Excel. Pengelompokan dilakukan dengan metode kuartil. Frekuensi (f) merupakan perhitungan jumlah responden yang menilai untuk masing-masing rating berdasarkan satu lansekap foto. Peluang kumulatif (cp) adalah frekuensi kumulatif dibagi jumlah responden. Nilai z diperoleh dengan program Microsoft Excel menggunakan rumus Normsinv dikali peluang kumulatif (Normsinv $x \mathrm{cp}$ ). Untuk nilai $\mathrm{cp}=1,00$ digunakan rumus $\mathrm{cp}=1-1 /(2 \mathrm{n})$ dan untuk nilai $\mathrm{cp}=0$ (z= tak terhingga) menggunakan rumus $\mathrm{cp}=1 /(2 \mathrm{n})$. Nilai rata- rata $\mathrm{z}$ yang diperoleh merupakan standar penilaian untuk menduga estetika pemandangan

\section{Hasil dan Pembahasan}

\subsection{Indeks Kenyamanan}

Berdasarkan pengukuran yang dilakukan di lapangan selama 5 minggu pada bulan Januari hingga Februari 2014, dengan parameter iklim yang diamati yaitu suhu dan kelembaban. Kategori kenyamanan di sepanjang jalan raya Desa Tegallalang pada bulan Januari hingga Pebruari 2014 termasuk kategori tidak nyaman. Nilai rata-rata THI 26,52, kurang nyaman untuk manusia yang berada di iklim tropis. Diena (2009) menyatakan bahwa indeks kenyamanan dalam kondisi nyaman ideal bagi manusia Indonesia berada pada kisaran THI 20-26. Indeks kenyamanan dengan pendekatan THI disajikan pada Tabel 1.

Tabel 1. Nilai THI Berdasarkan Suhu dan Kelembaban di Sepanjang Jalan Raya Tegallalang pada Bulan Januari sampai Februari 2014

\begin{tabular}{cccccc}
\hline Pengamatan & Tanggal & Rata- rata & Rata- rata & & THI \\
\cline { 5 - 6 } & pengamatan & suhu $\left({ }^{\circ} \mathrm{C}\right)$ & kelembaban(\%) & Nilai & Kondisi \\
\hline 1 & $09 / 01 / 2014$ & 29,52 & 63,83 & 27,39 & Tidak nyaman \\
2 & $16 / 01 / 2014$ & 28,36 & 62,95 & 26,26 & Tidak nyaman \\
3 & $23 / 01 / 2014$ & 26,06 & 69,55 & 24,47 & Sedang \\
4 & $30 / 01 / 2014$ & 29,51 & 60,38 & 27,17 & Tidak nyaman \\
5 & $06 / 02 / 2014$ & 29,66 & 60,86 & 27,34 & Tidak nyaman \\
& Rata- rata & 28,62 & 63,51 & 26,52 & Tidak nyaman \\
\hline
\end{tabular}

Nilai THI rata-rata di sepanjang jalan raya Desa Tegallalang setelah dikelompokkan menjadi 3 kondisi yaitu nyaman (20 - 23), sedang (24 - 26), dan tidak nyaman $>26$, pada bulan Januari hingga Februari 2014 dominan masuk kondisi tidak nyaman. Kondisi tidak nyaman terjadi pada 4 hari yaitu tanggal 9, 16, 30 Januari, dan 6 Februari 2014 dari 5 hari pengamatan yang dilakukan selama 5 minggu. Pengamatan 
lainnya yaitu tanggal 23 Januari 2014 termasuk kondisi kenyamanan sedang dengan nilai THI 24,47. THI di sepanjang jalan raya Desa Tegallalang tidak ada yang termasuk kondisi nyaman, hal tersebut diakibatkan oleh rendahnya elemen vegetasi yang ada di sepanjang jalan raya Desa Tegallalang. Elemen vegetasi yang biasanya terdapat pada areal telajakan depan rumah masyarakat sudah beralih fungsi menjadi artshop. THI tertinggi tercatat pada tanggal 9 Januari 2014 dengan nilai THI mencapai 27,39. Pada tanggal 9 Januari 2014 tercatat rata-rata suhu $29,52{ }^{\circ} \mathrm{C}$ dan rata-rata kelembaban $63,83 \%$. Nilai THI terendah tercatat pada tanggal 23 Januari 2014, dengan nilai THI 24,47. Tanggal 23 Januari 2014 rata-rata suhu sepanjang jalan Raya Desa Tegallalang $26,06{ }^{\circ} \mathrm{C}$ dan ratarata kelembaban 69,55\%. Faktor yang menyebabkan pada tanggal 23 Januari 2014 nilai THI sedang atau paling rendah dari pengukuran lainnya adalah karena pada hari tersebut terjadi hujan dengan nilai curah hujan $24 \mathrm{~mm} / \mathrm{hari}$ di Desa Tegallalang (data curah hujan lampiran 5)

\subsection{Estetika Lansekap}

\subsubsection{Kualitas Estetika Lansekap}

Hasil analisis SBE pada 45 lansekap di sepanjang jalan raya Desa Tegallalang, nilai SBE berkisar -80,21 hingga 138,42. Lansekap yang mempunyai nilai keindahan tertinggi adalah lansekap 18, lansekap ini merupakan lansekap berupa telajakan (Nilai SBE $=138,42$ ), yang artinya lansekap ini merupakan lansekap yang paling banyak diminati. Lansekap yang mempunyai nilai SBE terendah adalah lansekap 24 yang merupakan lansekap termasuk pedestrian (Nilai SBE $=-80,21$ ).

Berdasarkan sebaran normal, seluruh nilai SBE hasil evaluasi dikelompokkan ke dalam kualitas estetika rendah, sedang dan tinggi. Perhitungan untuk menentukan kelompok kualitas estetika dengan cara nilai SBE tertinggi dikurangi nilai SBE terendah dan dibagi jumlah kelas kelompok. Lansekap dengan nilai SBE <-7,33 termasuk ke dalam lansekap dengan kualitas estetika rendah, lansekap dengan nilai SBE antara -7,33 sampai 65,55 adalah lansekap dengan kualitas estetika sedang. Lansekap dengan nilai SBE $>65,55$ termasuk ke dalam lansekap dengan kualitas estetika tinggi.

\subsubsection{Kelompok Kualitas Estetika Lansekap}

Kualitas estetika lansekap dikelompokkan menjadi 3, yaitu kualitas estetika rendah, sedang dan tinggi. Estetika lansekap sepanjang jalan raya Desa Tegallalang dikelompokkan sebagaimana dapat dilihat pada Tabel 2. Lansekap sepanjang jalan raya Desa Tegallalang memiliki kualitas estetika rendah dengan 24 lansekap atau sekitar $53,33 \%$. Lansekap yang memiliki estetika sedang berjumlah 13 atau 28,88\%. Lansekap yang memiliki estetika tinggi hanya 8 lansekap atau $17,77 \%$. Hal ini sangat dipengaruhi oleh alih fungsi telajakan menjadi artshop karena dominan lansekap yang memiliki estetika tinggi ini adalah beberapa telajakan yang masih tersisa di sepanjang jalan raya Desa Tegallalang. Di samping elemen vegetasi yang berkurang karena adanya artshop, bahkan artshop yang dibangun tersebut juga kurang memiliki arsitektur yang menarik. Hal tersebut dapat dilihat dari bentuk, warna, dan ukuran bangunan yang kurang seragam, hal inilah 
yang dapat menurunkan kualitas estetika lansekap. Menurut Siregar (2004) bahwa bangunan dengan arsitektur yang menarik dapat memperkuat karakter lansekap sekitar, sehingga dapat mempengaruhi kualitas estetikanya. Sadik (2004) juga menambahkan bahwa perbaikan kualitas fisik bangunan khususnya pemberian warna pada tembok maupun atap bangunan, dapat mempengaruhi penilaian kualitas estetika yang cenderung meningkat.

Tabel 2. Kelompok Kualitas Estetika Lansekap Rendah, Sedang, dan Tinggi di Sepanjang Jalan Raya Desa Tegallalang

\begin{tabular}{llc}
\hline \multicolumn{1}{c}{ Kualitas estetika } & \multicolumn{1}{c}{ Lansekap } & Jumlah \\
\hline Rendah & $1,2,3,19,20,21,22,23,24,26,28,29,30,31,32$, & 24 \\
$(\mathrm{SBE}<-7,33)$ & $33,37,38,39,40,42,43,44,45$ & \\
& & 13 \\
Sedang & $4,5,6,8,9,11,12,15,25,27,34,36,41$ & \\
$(-7,33=$ SBE $=65,55)$ & & 8 \\
Tinggi & $7,10,13,14,16,17,18,35$ & \\
$(\mathrm{SBE}>65,55)$ & & \\
\hline
\end{tabular}

\subsubsection{Pengaruh Elemen Lansekap terhadap Kualitas Estetika}

\subsubsection{Elemen angkul-angkul}

Angkul-angkul dominan estetika sedang (38,46\%), estetika sedang (12,5\%) dan estetika rendah (12,5\%). Aangkul-angkul memiliki estetika sedang dipengaruhi oleh arsitekturnya yang menarik. Booth (1983) menambahkan, karakter bangunan seperti tekstur, warna, dan detil menentukan kualitas estetika di mana bangunan itu berada.

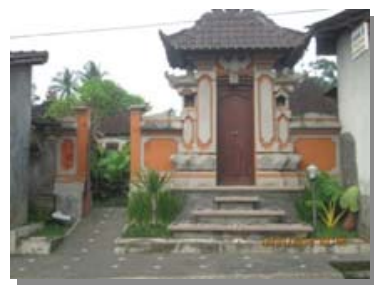

(a)

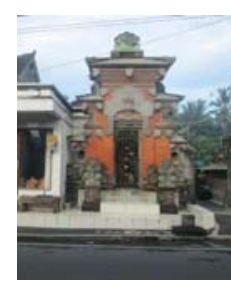

(b)

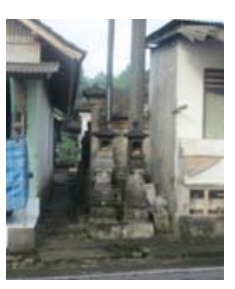

(c)

Gambar 1. Angkul-angkul. Keterangan: (a) estetika tinggi; (b) estetika sedang;

(c) estetika rendah

\subsubsection{Elemen telajakan}

Telajakan memberikan pengaruh yang tinggi terhadap kualitas estetika, dengan 75\% memiliki kualitas estetika tinggi, 23,07\%, estetika sedang, dan 0\% estetika rendah. Karakteristik telajakan yang umumnya didominansi oleh elemen vegetasi mampu meningkatkan kualitas estetika lansekap. Hal ini sesuai dengan penelitian Meliawati (2003) bahwa karakter yang menonjol dari lansekap dengan kualitas estetika tinggi adalah proporsi vegetasi yang cukup dominan, sehingga terkesan teduh dan nyaman. 


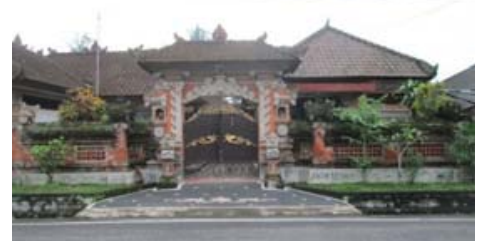

(a)

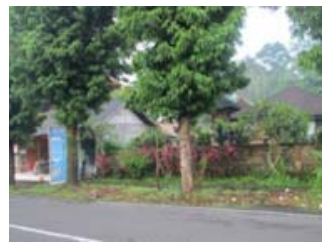

(b)

Gambar 2. Telajakan. Keterangan (a) estetika tinggi; (b) estetika sedang

\subsubsection{Elemen pedestrian}

Secara keseluruhan pedestrian di Desa Tegallalang memiliki kualitas estetika dominan rendah dan sedang. Rendahnya kualitas estetika pedestrian yang mencapai $29,16 \%$, dipengaruhi oleh kualitas pedestrian yang buruk dan perawatan yang kurang.

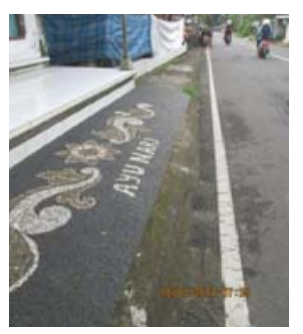

(a)

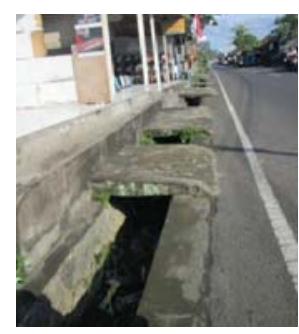

(b)

Gambar 3. Pedestrian. Keterangan (a) estetika sedang; (b) estetika rendah

\subsubsection{Elemen artshop}

Artshop cukup mempengaruhi kualitas estetika lansekap, hal tersebut diketahui dari elemen-elemen yang memiliki estetika rendah, 25\% adalah elemen artshop. Artshop memiliki estetika rendah karena bangunanya kurang menarik dan perawatan yang kurang. Sebesar 15,38\% memiliki estetika sedang, dan 12,5\% memiliki tinggi.

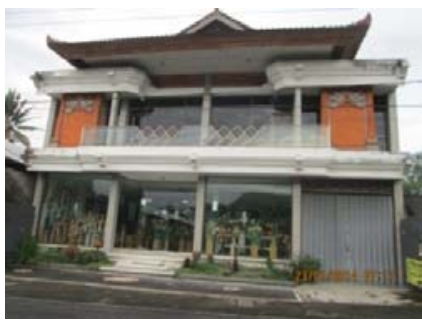

(a)

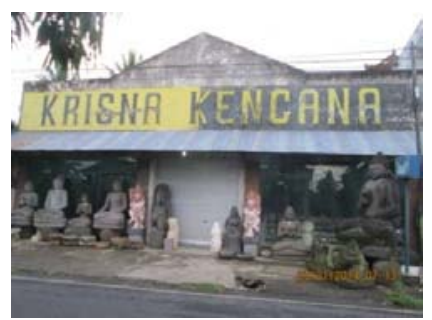

(b)

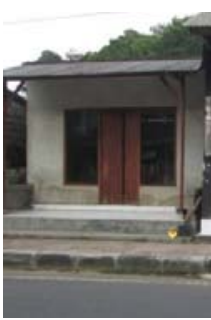

(c)

Gambar 4. Artshop. Keterangan (a) estetika tinggi; (b) estetika sedang; (c) estetika rendah

\subsubsection{Elemen jalan raya}

Kualitas estetika jalan raya Desa Tegallalang cenderung rendah. Nilai estetika jalan raya Tegallalang 33,33\% termasuk estetika rendah dari elemen lainnya yang memiliki estetika rendah. Rendahnya kualitas estetika jalan raya Desa Tegallalang disebabkan oleh rendahnya kualitas dan kurangnya kebersihan jalan raya. 


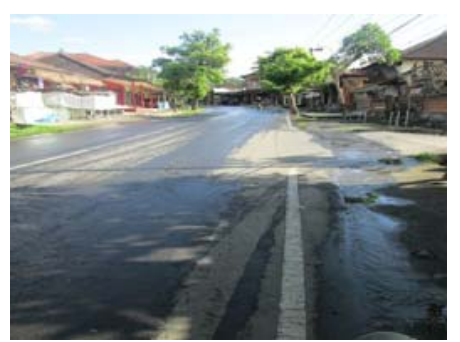

(a)

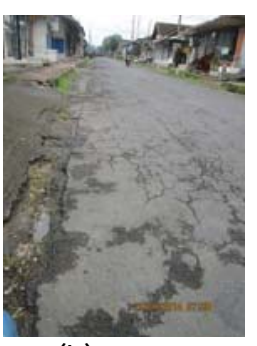

(b)

Gambar 5. Jalan Raya. Keterangan (a) estetika sedang; (b) estetika rendah

\section{Simpulan}

1. Kenyamanan di sepanjang jalan raya Desa Tegallalang berdasarkan nilai THI termasuk kategori kondisi tidak nyaman untuk manusia sebagai pengguna lansekap.

2. Kualitas estetika lansekap sepanjang jalan raya Desa Tegallalang tergolong rendah berdasarkan nilai SBE.

\section{Daftar Pustaka}

Booth, N. K. 1983. Basic Elements of Landscape Architecture Design. Waveland Press Inc., Illnois. $315 \mathrm{p}$.

Daniel, T.C. and R.S Boster. 1976. Measuring Landsape Aesthetic: The Scenic Beauty Estimation Method. US For., Serv., Res., Pap., RM-167.

Diena, A.L. 2009. Pengaruh Perubahan Penggunaan dan Penutupan Lahan Terhadap Kenyamanan di Suburban Bogor Barat. Skripsi (tidak dipublikasikan). Program Studi Arsitektur Lansekap. Fakultas Pertania Insitut Pertanian Bogor.

Fauzi, A. 2004, Ekonomi Sumber Daya Alam dan Lingkungan, Teori dan Aplikasi. Gramedia Pustaka Utama, Jakarta.

Khakhim, N. dkk. 2008. Analisis Preferensi Visual Lansekap Pesisir Daerah Istimewa Yogyakarta Untuk Pengembangan Pariwisata Pesisir Menuju Pada Pengelolaan Wilayah Pesisir Berkelanjutan. Forum Geografi, 22(1):44 - 59.

Meliawati. 2003. Kajian Karakteristik dan Elemen-elemen Pembentuk Kualitas Estetika Lansekap Kota Bogor. Skripsi (tidak dipublikasikan) Bogor: Fakultas Pertanian, Institut Pertanian Bogor.

Mustikaweni, R. 2008. Pengaruh Perubahan Pemanfaatan Ruang Kawasan Lingkar Luar Kebun Raya Bogor Terhadap Iklim Mikro. Skripsi (tidak dipublikasikan). Bogor: Program Studi Arsitektur Lansekap Fakultas Pertanian Institut Pertanian Bogor.

Nieuwolt, S.1998.Tropical Climatology, An Introduction to the Climates of the Low Latitude. New York: John Wiley and Sons.

Profil Desa Tegallalang. 2013. Desa Tegallalang. Hal 5-6.

Sadik, F. 2004. Evaluasi Perbaikan Kualitas Estetik Lansekap Pemukiman Kumuh di Kota Bogor dengan Simulasi Komputer. Skripsi (tidak dipublikasikan). Bogor: Fakultas Pertanian, Institut Pertanian Bogor. 
Siregar, F. 2004. Pengaruh Penutupan Vegetasi terhadap Kualitas Estetika pada Lansekap Pemukiman. Skripsi (tidak dipublikasikan). Bogor: Fakultas Pertanian, Institut Pertanian Bogor.

Statistik Daerah Kecamatan Tegallalang, $2012 . \quad$ Online. http://gianyarkab.bps.go.id/statdatgll-12/index.html. Diunduh 25 September 2013

Tjasyono, H.K.B. 1992. Klimatologi Terapan. Cet. I. Pionir Jaya, Bandung. 2004. Klimatologi, Ed. II. Penerbit ITB, Bandung. 